\title{
Design of Hydro Power by Using Turbines Kaplan on The Discharge Channel Paiton 1 and 2
}

\author{
Alvin K. Sosilo, Harsono Hadi, and Totok Soehartanto \\ Engineering Physics Dept. Institut Teknologi Sepuluh Nopember, Surabaya, Indonesia
}

\begin{abstract}
Condenser water from the discharge channel PJB Paiton discharged to the sea has the potential mechanical energy, because the flow rate of $7.6 \mathrm{~m} 3 / \mathrm{s}$ (if both discharge PJB Paiton function) and the discharge channel reaches a height of $4 \mathrm{~m}$. This paper will describe the design of hydro power (in the form of a block diagram) by using Kaplan turbine driven by utilizing the wastewater condenser. Kaplan turbine performance represented in the form of the relationship between the incoming water flow and the pitch angle (the angle between the propellers with a hub) to the torque generated. The simulation results indicate that the turbine torque is proportional to the mechanical power turbine. The greater the torque, the greater the mechanical power, and vice versa.
\end{abstract}

\section{Introduction}

In the steam power plant contained equipment such as boilers, condensers, turbines, generators, and pumps. The condenser is a heat exchanger, comprising the cooling water used to cool the steam turbine output. The steam will be condensed into water condensate, and condensate water will be fed back into the boiler using a pump (Syamsurijal, 2009). Thus, the cycle of the steam power plant is a closed cycle or cycles that do not require additional water during a sufficient condition. During operation, the condenser needs water as a cooling medium steam through heat exchange scheme.

After cooling the steam, the water will be discharged through a channel called discharge channel. Until now there has been no initiative to harness the water discharge channel's output, there is potential for enormous energy (discharge and water level discharge channel output of about $7.6 \mathrm{~m}^{3} / \mathrm{s}$ and $4 \mathrm{~m}$ ). This condition has the potential to be used as a system of Hydroelectric Power Plant (HPP).

Water turbine consists of several types, determination of water turbines in hydropower system design based on the characteristics of water flow (flow rates and falling stream). One type of water turbine is a Kaplan turbine. The pitch angle of the turbine Kaplan is the angle between the propeller with a hub. Variations in pitch angle and variations in water discharge, used for calculation of torque.

\section{Basic Theory}

\subsection{Condenser}

Condenser at hydroelectric plants is a heat exchanger, serves to cool the steam turbine output. The water condensation steam turbine output is called condensate water. Condensate water is the main source of water supply to the power plant boiler filler. Process on the steam power plant is a closed cycle; this is due to water vapor condensation turbine output is used again in a process in the boiler (Fig. 1).

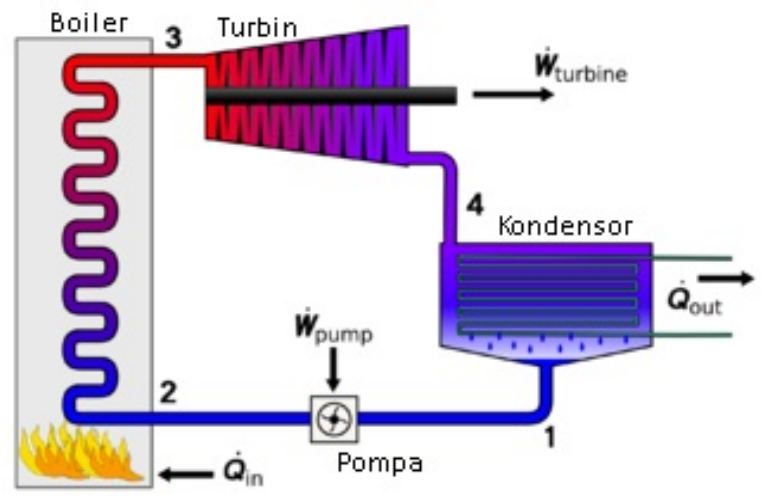

Fig. 1. Hydro power plant Cycle (Jumawa, C., 2013 


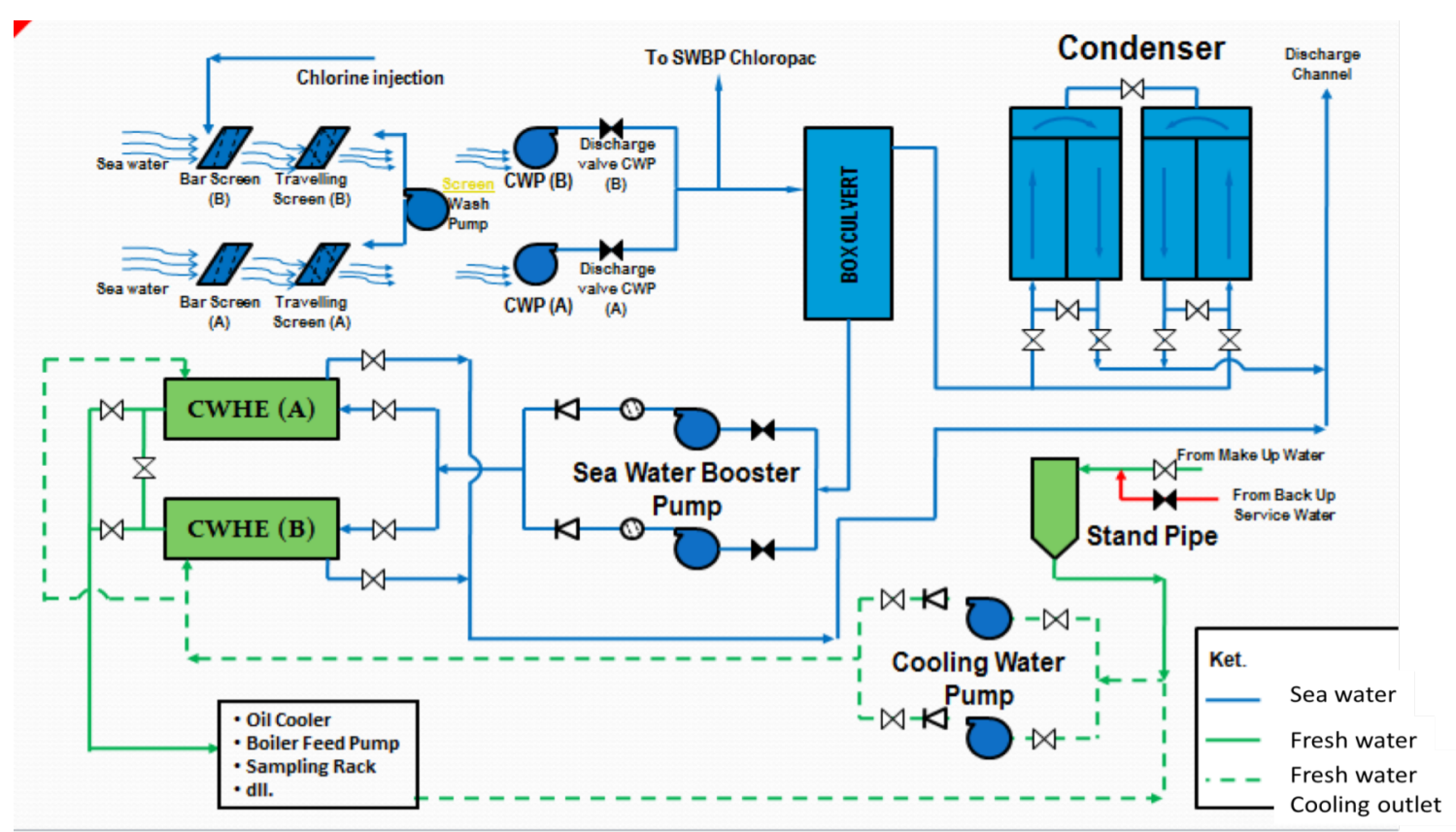

Fig. 2. Schema of discharge channel of HPP (Farzi, A, 2015)

\subsection{Discharge channel}

Conditioning water of condenser PJB Paiton use sea water (has undergone several processes, such as bar screen, traveling screen, screen wash pump, cooling water pump (CWP), water coolers are housed in box culvert, and then discharged as a cooling medium in the condenser. Conditioning water will be out towards the discharge channel (to dispose of condenser cooling water to the river). Here is a scheme of water flow in the discharge channel of steam power plants.

\subsection{Water Turbin Characteristic}

Water turbine has the characteristics stated in general by 6 pieces constants, among others (Luknanto, 2013):

\subsubsection{Speed Ratio $(\phi)$}

The speed ratio is the ratio between the translational speed of the turbine to the speed of the water through a nozzle with an altitude plunge $H$. Rated speed ratio is proportional to the height $\mathrm{H}$ of waterfalls on the turbine.

$$
\phi=\frac{V_{\text {linier }}}{\sqrt{2 g H}}=\frac{\frac{N \pi D}{60}}{\sqrt{2 g H}}
$$

$$
\begin{aligned}
& \mathrm{N}=\text { turbine rotational speed }(\mathrm{rpm}) \\
& \mathrm{D}=\text { diameter turbine }(\mathrm{m}) \\
& \mathrm{H}=\text { effective high waterfall } / \text { head }(\mathrm{m})
\end{aligned}
$$

\subsubsection{Unity speed}

Unity turbine speed is the rotational speed as a function of the diameter of the turbine and high waterfalls from the discharge channel.

$$
\begin{aligned}
& N=84,6 \phi \frac{\sqrt{H}}{D} \\
& N_{U}=84,6 \phi
\end{aligned}
$$

\subsubsection{Unity discharge}

Unity discharge that goes to the turbine as a function of the diameter of the turbine and high-plunge from the discharge channel.

$$
\begin{aligned}
& Q_{U}=C_{d} \frac{1}{4} \pi \sqrt{2 g}=\frac{Q}{D^{2} \sqrt{H}} \\
& \mathrm{Q}=\text { water discharge on turbines }\left(\mathrm{m}^{3} / \mathrm{s}\right) \\
& C_{d}=\text { coefficient of discharge }
\end{aligned}
$$

\subsubsection{Unity power}

Turbine power generated proportional to the diameter and height of the discharge channel plunge.

$$
\begin{aligned}
P_{U}= & \eta \rho g Q_{U} \\
= & \frac{P}{D^{2} H^{3 / 2}} \\
& \mathrm{P}=\text { mechanical power turbine(watt) } \\
& \rho=\text { the density of water }\left(\mathrm{kg} / \mathrm{m}^{3}\right) \\
\mathrm{g} & =\text { acceleration of gravity }\left(\mathrm{m} / \mathrm{s}^{2}\right) \\
& \eta=\text { turbine efficiency }
\end{aligned}
$$

\subsubsection{Diameter Specification}

Diameter turbines are needed to produce one unit of power at high waterfall $\mathrm{H}$.

$$
D_{s}=\frac{1}{\sqrt{P_{U}}}=\frac{D H^{3 / 4}}{\sqrt{P}}
$$

\subsubsection{Specific Speed}

Rotational speed turbines to produce one unit of power at high waterfall $\mathrm{H}$. 


$$
=\frac{N \sqrt{P}}{H^{5 / 4}} N_{S}=\sqrt{P_{U}} N_{U}
$$

In addition to the six constants above, there are also other important characteristics in water turbines, namely:

\subsubsection{Torque Turbine}

The energy generated by the turbine rotates due to the flow of water takes. Water turbine torque can be obtained from the equation of impulse and momentum [3].

$$
d F_{a / p}=\frac{d m V_{r e l}}{d t}
$$

\subsubsection{Turbine efficiency}

Comparison between the mechanical power generated by the turbine to power the turbine water flow [4]

$$
=\frac{\tau \omega}{\rho Q g H} \eta=\frac{P}{\rho Q g H}
$$

\subsection{Selection of water turbines}

There are some parameters in determining the types of water turbines, among others (Patty, 1995):

\subsubsection{High effective waterfall (head) and discharge that will be used to drive a turbine.}

In Fig. 3 shows the graph turbine type selection based on the height $\mathrm{H}$ and discharge.

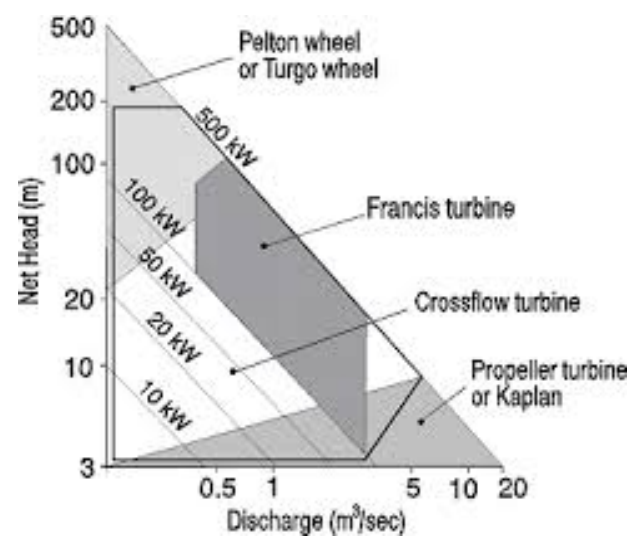

Fig. 3. Types of turbines based head \& discharge

Pelton turbine is suitable for high head, and low flow while effectively Kaplan turbines for low head and flow profusely. Francis turbines and crossflow turbines for head and low flow-medium.

\subsubsection{Specific Speed Turbine}

The value range of specific speed turbine water:

- $\mathrm{N}_{\mathrm{s}}=9-25$ (Pelton turbine with one jet)

- $\mathrm{N}_{\mathrm{s}}=25-60$ (Pelton turbine with more than one jet)

- $\quad \mathrm{N}_{\mathrm{s}}=40-400$ (Francis turbine)

- $\quad \mathrm{N}_{\mathrm{s}}=260-860$ (Kaplan turbine)
Specific Kaplan turbine speed can be calculated using equation

$$
N_{S}=\frac{9431}{H+9,75}+155
$$

\section{Hydro power design}

In this study, Kaplan turbines will be placed under the discharge channel as shown in Fig. 4.

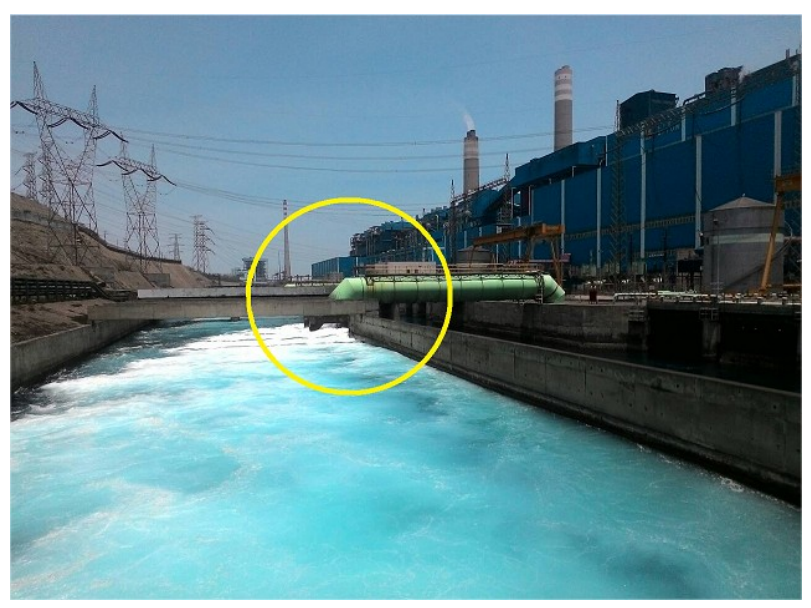

Fig. 4. Position Kaplan turbine

Installation of the system is still not there, then the channel discharge channel contained in steam power plants have to be modified in order Kaplan turbine placement can be done well.

\subsection{Block Diagram of hydro power}

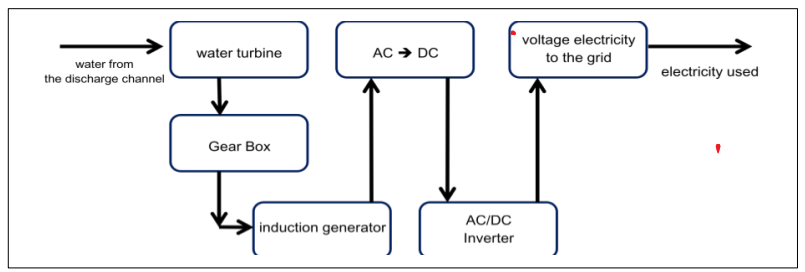

Fig. 5. Block diagram of hydro power system

Water discharge channel output will hit Kaplan turbine so that the turbine rotates. Turbine connected to a generator rotor through a gearbox. rotor spinning will make the generator produces alternating electrical voltage. This electrical voltage is rectified because the energy reservoir hydropower system is erratic. voltage electricity supplied is alternating electrical voltage, the voltage that has been rectified converted back to an alternating electrical voltage by a DC / AC Inverter before being connected to a voltage mesh nets.

This paper represents only the components of the turbine, gearbox, and generator. discussion after the generator components are recommendations that can be given for the reasons mentioned above. 


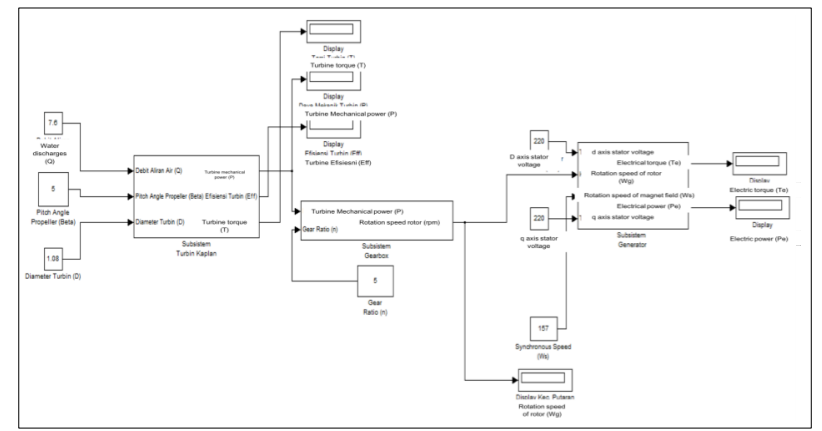

Fig. 6. Modelling the whole system

The system consists of three major subsystems, namely the water turbine, gearbox, and generator induction.

Input system:

- Water flow rate $(\mathrm{Q}),\left(\mathrm{m}^{3} / \mathrm{s}\right)$

- pitch angle $(\beta),($ degree)

- turbine diameter (D), (m)

- gear ratio $(\mathrm{n})$

Output system:

- turbine torque $(\tau),(\mathrm{Nm})$

- mechanical power of turbine (P), (watt)

- turbine efficiency (\%)

- the rotated speed of rotor generator $\left(\omega_{\mathrm{g}}\right),(\mathrm{rad} / \mathrm{s})$

- electrical torque $\left(\mathrm{T}_{\mathrm{e}}\right),(\mathrm{Nm})$

- electrical power $\left(\mathrm{P}_{\mathrm{e}}\right)$, (watt)

\subsection{Hydro turbine block system}

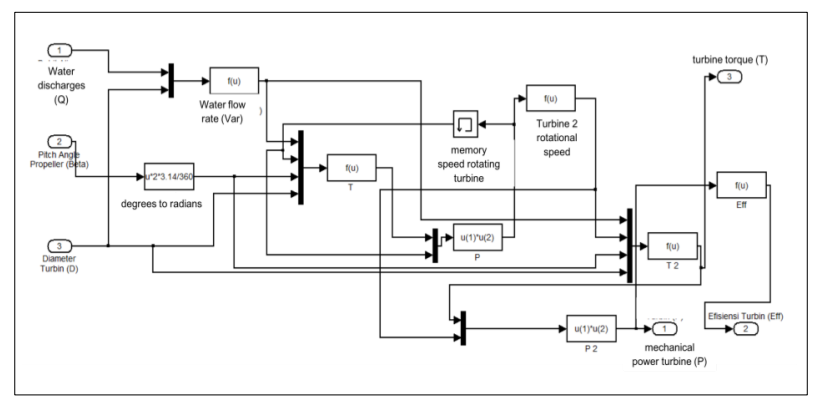

Fig. 7. Modeling sub-system of water turbines

Input:

- Water flow rate $(\mathrm{Q}),\left(\mathrm{m}^{3} / \mathrm{s}\right)$

- pitch angle $(\beta),($ degree)

- turbine diameter (D), (meter)

Output:

- turbine torque $(\tau),(\mathrm{Nm})$

- mechanical power of turbine (P), (watt)

- turbine efficiency (\%)

\subsection{Determining of turbine type}

Turbine type is determined through the selection of a water turbine curves (Fig. 8).

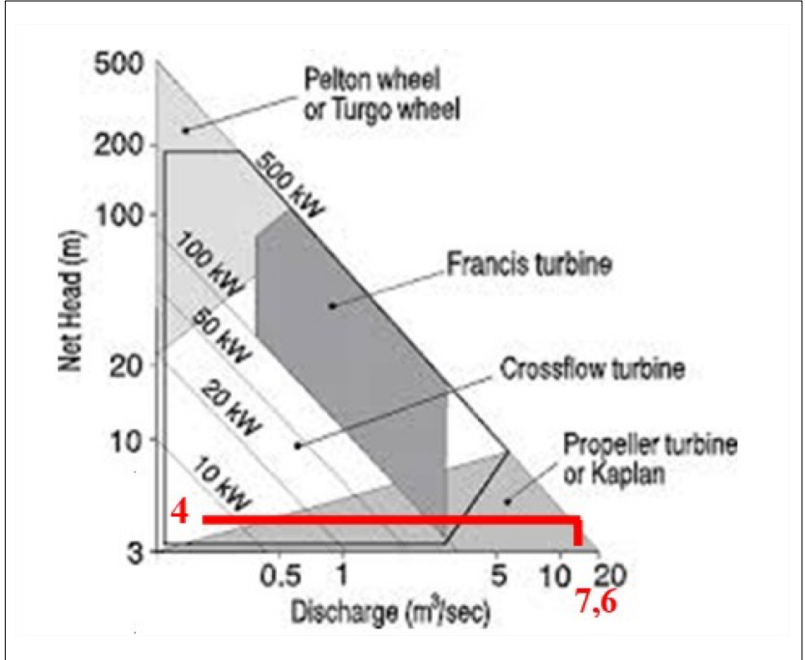

Fig. 8. Determination the type of turbine based on flow rate and altitude

Through the Fig. 8, it was found that the type of turbine that is suitable for the conditions of the discharge channel PJB Paiton is Kaplan turbines or propellers.

The determination of the specific speed (NS) using Equation 6 (for the height $\mathrm{H}=4 \mathrm{~m}$ ):

$$
\begin{aligned}
& N_{S}=\frac{9431}{H+9,75}+155 \\
& =840,89
\end{aligned}
$$

NS value calculation results in accordance with NS value for Kaplan turbines (in the range 260-860).

\subsection{Determination of turbine dimension}

Dimensions calculated based on the Kaplan turbine propeller diameter and number of propellers. wicket gate which is part of the steering flow of water, its dimensions are based on previous research [6]. Wicket gate opening angle of $30^{\circ}$

Discharge water before entering and after exiting the wicket gate assumed to be the same so that the propeller diameter (D) defined by the equation 5 , namely:

$$
D=c Q^{0,5}
$$

C value is determined based on Table 1, was obtained: $\mathrm{c}=0.39$ for the value of $\mathrm{H}$ in the range of $5 \mathrm{~m}$.

Table 1. Determination coefficient value c [1]

\begin{tabular}{|c|c|c|c|c|c|}
\hline $\mathrm{H}(\mathrm{m})$ & 5 & 10 & 15 & 20 & 25 \\
\hline $\mathrm{C}$ & 0,39 & 0,37 & 0,37 & 0,36 & 0,36 \\
\hline
\end{tabular}

By entering a value of $\mathrm{Q}=7.6 \mathrm{~m}^{3} / \mathrm{s}$ then obtained:

$$
=1.08 \mathrm{~m}
$$

The number of the propeller $(Z)$ is determined by Table 2 (based on $\mathrm{N}_{\mathrm{s}}$ values have been obtained). $Z=4$ for NS value in the range of 800 . 
Table 2. Determination of Number of Turbine Blade Runner

\begin{tabular}{|c|c|c|c|c|c|}
\hline \multicolumn{5}{|c}{$(\mathrm{Z})$} \\
\hline Ns (Hp) & 400 & 500 & 600 & 700 & 800 \\
\hline Ns (kW) = 0,857Ns & 340 & 430 & 510 & 600 & 680 \\
\hline Z & $8-6$ & $7-6$ & $6-5$ & $5-4$ & 4 \\
\hline
\end{tabular}

Kaplan turbines are used to have the initial specification as follows:
Diameter (D)
$=1,08 \mathrm{~m}$,
Number of propeller (Z)
$=4$ unit,
wicket gateopening
$=30^{\circ}$.

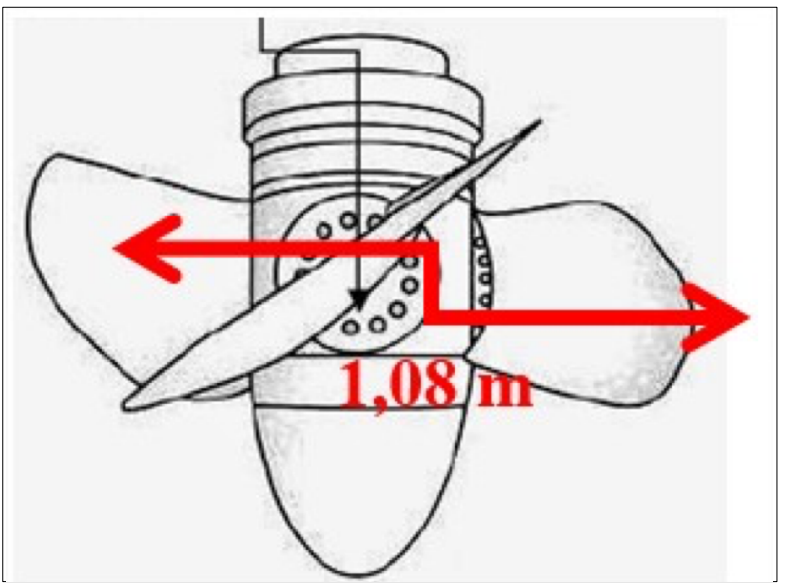

Fig. 9. Part propeller turbines Kaplan

\subsection{Determining gear box parameter}

Parameter gearbox is required as the coefficient convert the turbine to the generator output. In this study, the parameters used in the gearbox is the gear ratio (n).

Gear ratios will be used as one input parameter and varied. Gear ratio according to Kaplan turbines ranges from 1: 3 to $1: 7$ (http://directindustry.com). $\mathrm{N}$ input values determined in the modeling with:

$$
\mathrm{n}_{1}=5 ; \mathrm{n}_{2}=6 ; \text { and } \mathrm{n}_{3}=7
$$

\section{Analysis And Discussion}

Pitch Angle Torque relationship with Power Turbine and Turbine Mechanics.

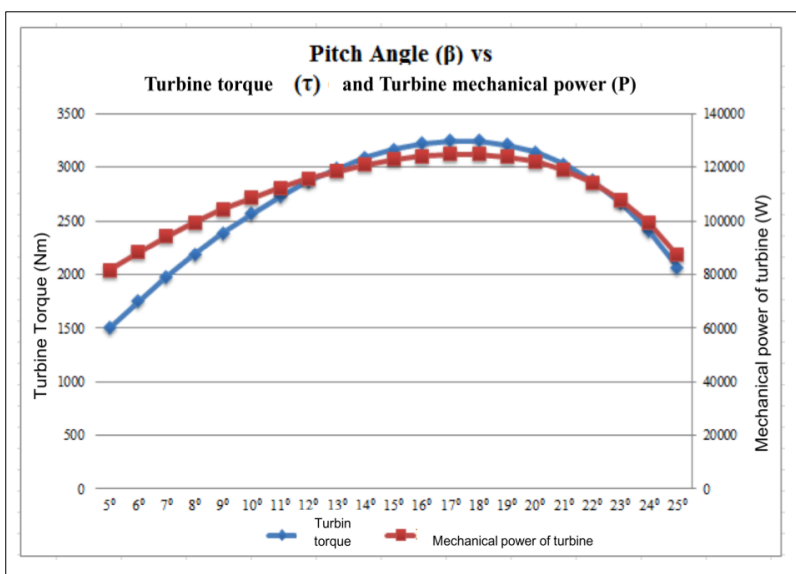

Fig. 10. Graph relationship with the pitch angle torque and mechanical power turbine
Turbine torque is proportional to the mechanical power turbine. large torque obtained in the range of pitch angle $15^{\circ}-20^{\circ}$ with maximum values of $3249.7 \mathrm{Nm}$ on the pitch angle $17^{\circ}$. torque of the turbine will have an impact on mechanical power turbines are getting bigger, the pitch angle range will generate maximum value $124,987.1 \mathrm{~W}$ or $125 \mathrm{~kW}$.

\section{Acknowledgment}

Acknowledgements to PJB Paiton that provides opportunities for writers to do the design of hydropower by utilizing the condensate flow from the discharge channel.

\section{References}

1. I. Akbar, Studi Kelayakan dan Penyusunan Basic Design Proyek PLTA Siteki. Vol. 1 Bab 3 "Parameter Design Optimum" (2003)

2. S. Chapman, Electric Machinery Fundamentals 4th edition (2005)

3. A. Crawford, J. Motley, Modeling Torque of a Hydro-Turbine (2011)

4. M. Gustafsson, Improved Governing of Kaplan Turbine Hydropower Plants Operating Island Grids (2013)

5. http://engineeringtoolbox.com/electrical-motors-hptorque-rpm-d 1503.html diakses 13 Januari 2016 pukul 17.00.

6. A. Susanto, Perancangan dan Pengujian Turbin Kaplan pada Ketinggian $(\mathrm{H}) 4 \mathrm{~m}$ Sudut Sudut Pengarah $30^{\circ}$ dengan Variabel Perubahan Debit (Q) dan Sudut Sudu Jalan. Jurusan Teknik Mesin Fakultas Teknik. Universitas Muhammadiyah. Surakarta, 2013.

7. A. Farzi, Sistem Pendingin. PT. PJB UP Gresik. (2015)

8. C. Jumawa, Pembangkit Listrik Tenaga Uap. Group Riset CFD Indonesia. Ahmad Indra Research. Universitas Indonesia. Depok (2013)

9. D. Luknanto, Bangunan Tenaga Air. Jurusan Teknik Sipil Fakultas Teknik. Universitas Gadjah Mada. Yogyakarta (2013)

10. O. Patty, Tenaga Air. Surabaya: Erlangga (1995) 